
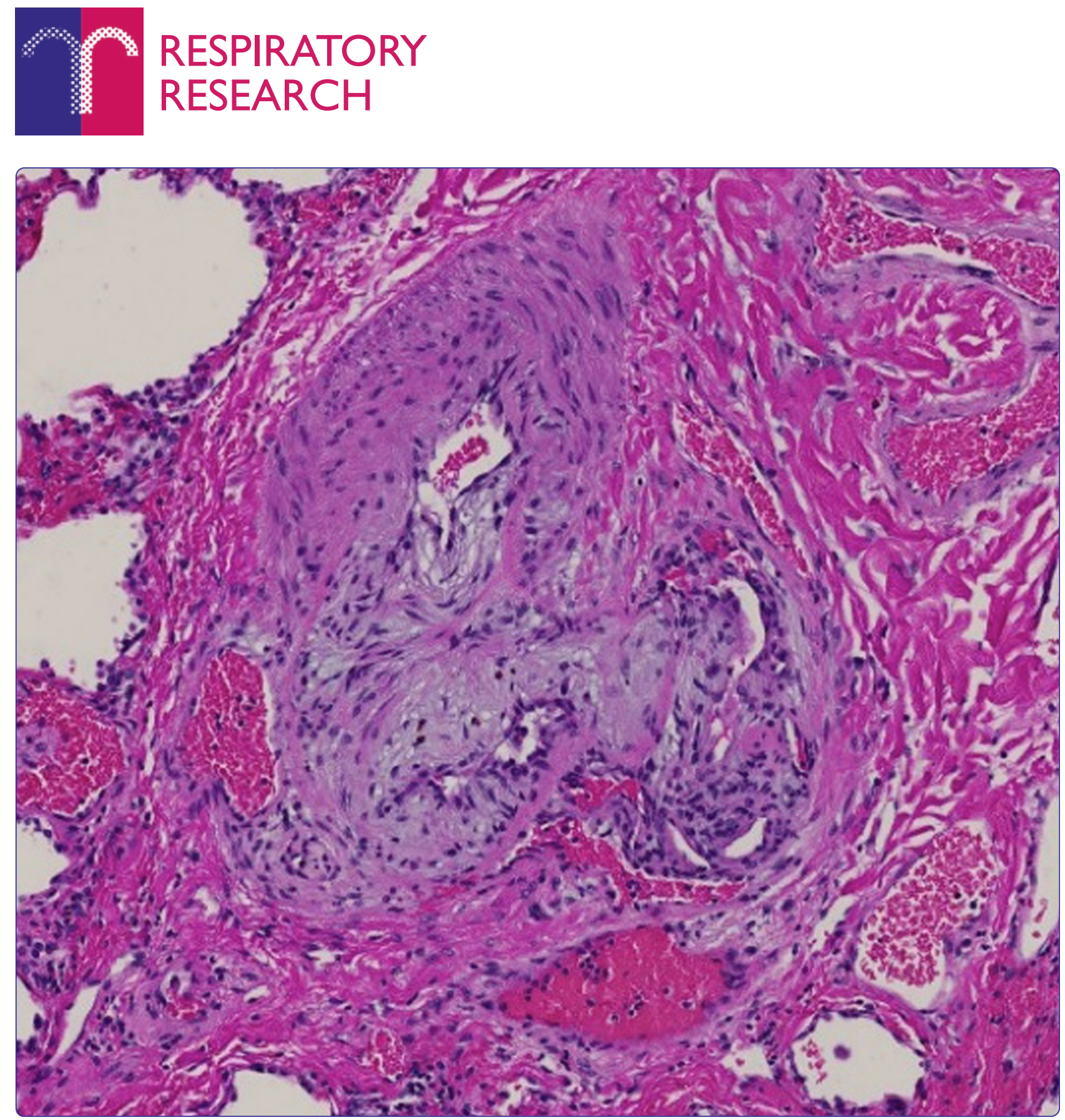

\title{
Inflammatory cytokines in pulmonary hypertension
}

Groth et al. 


\title{
Inflammatory cytokines in pulmonary hypertension
}

\author{
Alexandra Groth ${ }^{1}$, Bart Vrugt ${ }^{2}$, Matthias Brock ${ }^{1}$, Rudolf Speich', Silvia Ulrich and Lars C Huber ${ }^{1 *}$
}

\begin{abstract}
Pulmonary hypertension is an "umbrella term" used for a spectrum of entities resulting in an elevation of the pulmonary arterial pressure. Clinical symptoms include dyspnea and fatigue which in the absence of adequate therapeutic intervention may lead to progressive right heart failure and death. The pathogenesis of pulmonary hypertension is characterized by three major processes including vasoconstriction, vascular remodeling and microthrombotic events. In addition accumulating evidence point to a cytokine driven inflammatory process as a major contributor to the development of pulmonary hypertension.

This review summarizes the latest clinical and experimental developments in inflammation associated with pulmonary hypertension with special focus on Interleukin-6, and its role in vascular remodeling in pulmonary hypertension.
\end{abstract}

Keywords: Pulmonary hypertension, Inflammation, Immune cells, Experimental models, Cytokines, microRNAs

\section{Introduction}

Pulmonary hypertension summarizes various conditions in which the blood pressure in the pulmonary circulation is significantly elevated. By definition, pulmonary hypertension is diagnosed when the mean pulmonary arterial pressure (mPAP) exceeds $25 \mathrm{mmHg}$ as measured by right-heart catheterization. Since the first international conference by the World Health Organization (WHO) in Geneva in 1973, the classification of pulmonary hypertension was subjected to many changes. The current classification is based on the WHO-Conference in Nice (2013) [1] and separates the term pulmonary arterial hypertension (PAH) from pulmonary hypertension $(\mathrm{PH})$ due to left heart disease, pulmonary disease, chronic thromboembolic pulmonary hypertension (CTEPH) and $\mathrm{PH}$ of miscellaneous etiologies. The current classification is summarized in the list 'Updated clinical classification of pulmonary hypertension (Nice, 2013)' below [1].

\section{Updated clinical classification of pulmonary hypertension} (Nice, 2013) [1]

1. Pulmonary arterial hypertension (PAH)

1.1. Idiopathic PAH

1.2. Heritable PAH

\footnotetext{
* Correspondence: lars.huber@usz.ch

'Division of Pulmonology, University Hospital Zurich, Rämistrasse 100, $\mathrm{CH}-8091$ Zurich, Switzerland

Full list of author information is available at the end of the article
}

\subsubsection{BMPR2}

1.2.2. ALK1, ENG, SMAD9, CAV1, KCNK3

1.2.3. Unknown

1.3. Drug- and toxin-induced

1.4. Associated with

1.4.1. Connective tissue diseases

1.4.2. HIV infection

1.4.3. Portal hypertension

1.4.4. Congenital heart diseases

1.4.5. Schistosomiasis

1' Pulmonary veno-occlusive disease and/or pulmonary capillary hemangiomatosis

1" Persistent pulmonary hypertension of the newborn (PPHN)

2. Pulmonary hypertension due to left heart disease

2.1. Left ventricular systolic dysfunction

2.2. Left ventricular diastolic dysfunction

2.3. Valvular disease

2.4 Congenital/acquired left heart inflow/outflow tract obstruction and congenital cardiomyopathies

3. Pulmonary hypertension owing to lung diseases and/ or hypoxia

3.1. Chronic obstructive pulmonary disease

3.2. Interstitial lung disease

3.3. Other pulmonary diseases with mixed restrictive and obstructive pattern

3.4. Sleep-disordered breathing

3.5. Alveolar hypoventilation disorders 
3.6. Chronic exposure to high altitude

3.7. Developmental abnormalities

4. Chronic thromboembolic pulmonary hypertension (CTEPH)

5. Pulmonary hypertension with unclear multifactorial mechanisms

5.1. Hematologic disorders: chronic haemolytic anemia, myeloproliferative disorders, splenectomy

5.2. Systemic disorders: sarcoidosis, pulmonary histiocytosis, lymphangioleiomyomatosis

5.3. Metabolic disorders: glycogen storage disease, Gaucher disease, thyroid disorders

5.4. Others: tumoral obstruction, fibrosing mediastinitis, chronic renal failure, segmental $\mathrm{PH}$

The pathophysiological mechanisms of pulmonary hypertension are not fully understood. Despite the clinical heterogeneity of the entities listed in 'Updated clinical classification of pulmonary hypertension (Nice, 2013)' [1] a common pathway resulting from a combination of genetic susceptibility and environmental factors seems to play a pivotal role in the pathogenesis of pulmonary hypertension. This pathway is characterized by vasoconstriction due to constrictive agents such as endothelin-1 [2], an imbalance of vasodilators (e.g. nitric oxide $(\mathrm{NO})$ and prostacyclin) (e.g. endothelin-1) microthrombosis as well as vascular remodeling. Depending on the specific entity that causes the elevation of pulmonary pressure, these three factors are present in most forms of pulmonary hypertension. Oral anticoagulation and specific vasodilators are employed to address vasoconstriction and in situ thrombosis. However, in pulmonary hypertension the currently available drugs are insufficient to reverse vascular remodeling. Vascular remodeling is characterized by smooth muscle cell proliferation, hypertrophy of the medial layer, arteriolar muscularization and endothelial cell proliferation. Numerous factors have been identified that might trigger ongoing remodeling of the vessel wall but the bone morphogenetic protein receptor type II (BMPR2), which is predominantly expressed on pulmonary endothelium and smooth muscle cells, is considered to be the master regulator of vascular remodeling in pulmonary hypertension. Mutations or non-genetic alterations, such as the downregulation of this receptor, might lead to the vasculopathic lesions observed in patients with pulmonary hypertension. In up to $70 \%$ of familial $\mathrm{PAH}$ and in up to $30 \%$ of idiopathic PAH patients are carriers of BMPR2 mutations.

\section{Review}

Evidence from animal models and studies in patients with pulmonary hypertension suggest that inflammation contributes to the development of pulmonary hypertension, in particular in PAH. In lung biopsies from patients with $\mathrm{PAH}$, mononuclear cells are often observed in plexiform lesions, mainly consisting of $\mathrm{T}$ cells, macrophages and, to a lesser extent B cells [3]. A recent study revealed that the degree of perivascular inflammation correlates with both vascular wall thickness as well as mPAP [4]. The increased prevalence of PAH in patients with inflammatory diseases like thyroiditis [5] and in autoimmune disorders including connective-tissue diseases [6] further indicates an important role for the inflammatory process in the pathogenesis of the disease.

\section{Monocytes \& macrophages}

Increased numbers of macrophages are present in pulmonary lesions from patients with severe PAH [7]. Activation of macrophages induces the release of IL-1 $\beta$, IL- 6 , tumor necrosis factor- $\alpha$ (TNF-alpha), and IL-10, which all play an important role in the pathogenesis of PAH [8]. Furthermore activated macrophages may present antigens to $\mathrm{T}$ cells resulting in $\mathrm{T}$-cell activation and $\mathrm{T}$-cell derived cytokine production, which further facilitates the inflammatory process associated with PAH [9]. Macrophages in mice with hypoxia-induced $\mathrm{PH}$ seem to switch their phenotype in a more activated type due to hypoxia and upregulate expression of genes involved in inflammatory processes (i.e. IL-1 $\beta$, IL-13) [10]. Interestingly this switch may be caused by IL- 6 , one of the major elevated cytokine in PAH [11].

\section{T cells}

$\mathrm{T}$ cells are increased in pulmonary vasculature in lungs from PAH patients. Cytotoxic CD8+ T cells even constitute the major part of the inflammatory component in plexiform vascular lesions. The nuclear factor of activated T cells (NFAT), a transcription factor that promotes cytokine gene transcription, is upregulated in $\mathrm{PAH}$, leading to increased levels of cytokines, a main feature of PAH [12]. $\mathrm{T}$ cell deficient rats are more likely to develop PAH and deficiency of $\mathrm{CD} 8+\mathrm{T}$ cells in PAH patients correlated with a worse survival, which indicate that $\mathrm{T}$ cells play a protective role during the development of $\mathrm{PH}$ [13]. Various pathways are likely to generate this protective effect, for example Treg (T regulatory) cells might prevent the development of pulmonary hypertension and margin endothelial injuries, through the upregulation of BMPR2 in lung tissue [14]. T cells have been shown to downregulate the macrophage-mediated inflammatory angiogenesis in the lung [7].

\section{B-cells}

B-cell differentiation is stimulated by $\mathrm{CD} 4+\mathrm{T}$ helper (Th) cells. These stimulated B cells produce autoantibodies which may explain the increased levels of antinuclear 
antibodies generally found in PAH patients [15]. Compared with non idiopathic PAH patients, B cells in peripheral blood from idiopathic PAH patients show a different RNA expression profile suggesting that in PAH patients B cells are activated [16].

Figure 1 shows the different inflammatory cells present in vasculopathic lesions of a patient with $\mathrm{PAH}$.

\section{Cytokines}

Cytokines represent a large group of signaling proteins that are produced and secreted by cells of the immune system and regulate numerous biological processes including inflammation, immunity and hematopoiesis. Cytokines are specific mediators that interact in an autocrine, paracrine or endocrine fashion.

Cytokines emerged as major contributing factors in the pathogenesis of pulmonary hypertension [17-19]. In addition, cytokines might act as biomarkers both for diagnosis and clinical outcome of patients with pulmonary hypertension. Here we review experimental results and clinical data of the most important cytokines in pulmonary hypertension. Several novel experimental and transgenic models have been described in the context of pulmonary hypertension [20] but it is unclear whether the findings in these models can be extrapolated to the human situation. The two best established models to date are the monocrotaline (MCT) and hypoxia induced model. Increased vascular remodeling has been observed by addition of an angiogenesis inhibitor, a modifying extension known as the "Sugen hypoxia" model. This model is promising to become a more physiological surrogate of the human disease.
However, also in this model little is known about the contribution of inflammation.

\section{Specific cytokines \\ IL-1 $\beta$}

Clinical data: Elevated serum levels of IL-1beta were found in PAH patients and correlate with a worse outcome [21]. In a case report, the IL-1beta receptor antagonist Anakinra was shown to resolve pulmonary hypertension in a patient with Adult-Onset Still's Disease [22].

Experimental evidence: In hypoxia-induced pulmonary hypertension and in the MCT model, data on IL-1 $\beta$ were found to diverge: in the MCT model, high levels of IL- $1 \beta$ were measured and, conversely, treatment with an IL-1 $\beta$ receptor antagonist reduced pulmonary hypertension and right ventricular hypertrophy, while no such findings were reported in the hypoxia mouse model [23]. This difference might be due to the action of MCT, a pyrrolizidine alkaloid with highly toxic and, potentially, inflammatory effects. In some studies, a link between levels of IL-1 $\beta$ and prostacyclins, in particular PGI2, was described: PGI2 is a metabolite of arachidonic acid with vasodilating and antiproliferative properties. The vasodilating effects are mediated through the second messenger cyclic adenosine monophosphate (cAMP). Patients with pulmonary hypertension have significantly decreased expression of endogenous PGI2 [24]. Interestingly, IL-1 $\beta$ enhances the expression of PGI2 in human pulmonary artery smooth muscle cells [25]. Similarly, in rat PASMC, IL-1- $\beta$ increased the expression of PGI2 and 6-ketoPGF1 $\alpha$, a stable metabolite of PGI2 [26]. The increased

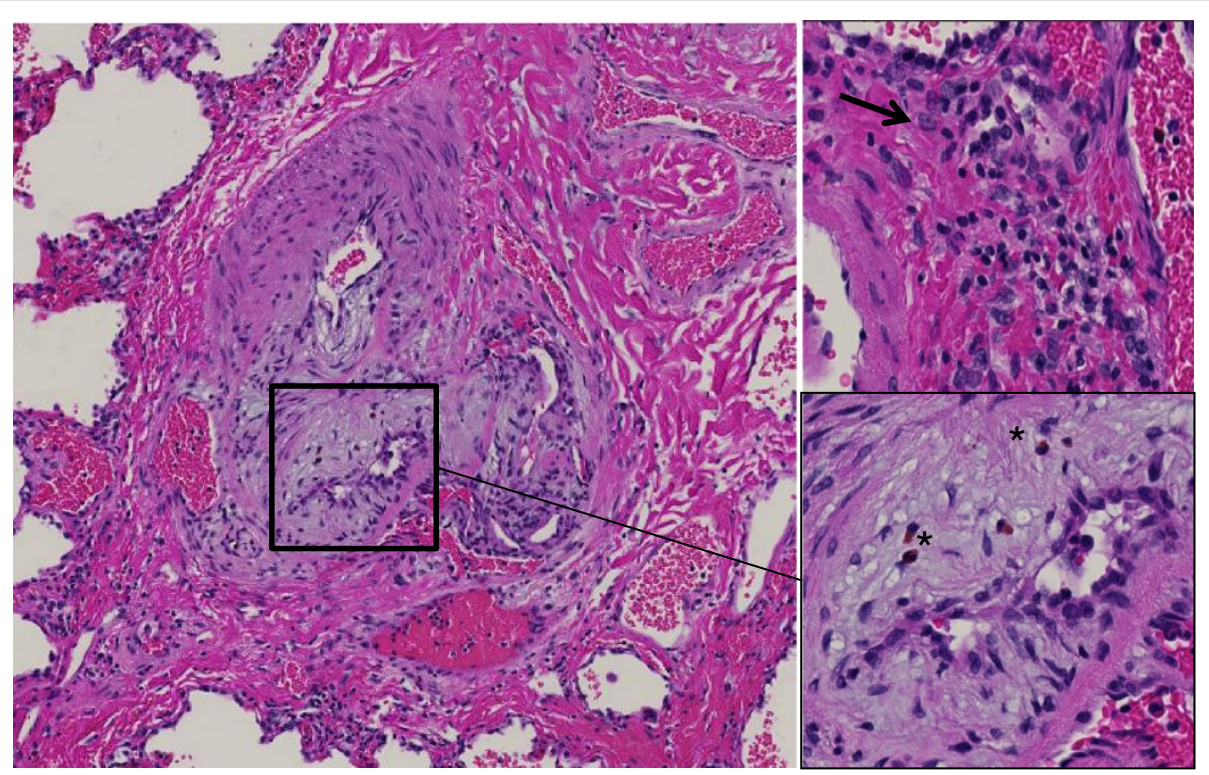

Figure 1 Plexiform lesion in a patient with PAH. Complex vascular lesion with perivascular fibrosis and infiltration by lymphocytes, plasma cells (arrow head) and eosinophils (*). HE staining. 
expression of PGI2 might represent an endogenous response to the inflammatory injuries in the lung tissue. Itoh et al. measured an increase of the cyclooxygenase (COX)-2 mRNA in PASMC treated with IL-1 $\beta$ [26]. COX-2 is a key enzyme in the regulation of prostaglandin synthesis. Bradbury et al. showed that IL-1 $\beta$ induces COX-2 [27] an, in a follow-up paper, the authors showed that adenylyl cyclase, which converts adenosine triphosphate (ATP) to cAMP is downregulated by IL-1 $\beta$. Moreover, accumulation of cAMP was attenuated in response to PGI2 analogues in human PASMCs, which is presumably due to COX-2 induction [28].

IL-18, a pro-inflammatory cytokine and member of the IL- 1 family, is activated by the cleavage of IL- $1 \beta$-converting enzyme, generating the biologically active IL-18. IL-18 is elevated in the patients with PAH and there is evidence that abnormal levels of IL-18 play a role in vasculopathy of the pulmonary circulation [29]. A recent study demonstrated that vascular injury may lead to an upregulation of IL-18 from PASMC of the medial vessel layer. IL-18 acts through an autocrine or paracrine effect on smooth muscle cells via its receptor, IL-18R $\alpha$, causing proliferation and recruitment of other smooth muscle cells. These mechanisms contribute to transmigration of PASMC and to hypertrophy of the medial vessel layer [29].

A recent study demonstrated that vascular injury may lead to an upregulation of IL-18 from PASMC of the medial vessel layer. IL-18 acts through an autocrine or paracrine effect on smooth muscle cells via its receptor, IL-18R $\alpha$, causing proliferation and recruitment of other smooth muscle cells. These mechanisms contribute to transmigration of PASMC and to hypertrophy of the medial vessel layer [29].

Potential implications: These data implicate that IL-1 $\beta$ appears to have deleterious effects for the development and progression of pulmonary hypertension. The exact mechanisms, however, remain unclear and therapeutic inhibition of IL- $1 \beta$ is limited to anecdotal case reports precluding therapeutic use at this moment.

\section{IL-6}

IL-6 is an important mediator in hepatic acute phase response [30] and is produced by inflammatory cells, i.e. monocytes and T-lymphocytes. As suggested by recent publications, IL- 6 might be one of the most important cytokines involved in the pathogenesis of PAH and hypoxia-induced pulmonary hypertension.

Clinical data: Serum levels are significantly higher in patients as compared with normal controls [31]; the levels were found to correlate with patients survival and levels of IL-6 also turned out to be a better predictor for survival than traditional clinical tests (e.g. the 6-minute walking distance and hemodynamic measurements) [21,32]. Moreover, IL-6 seems to have a strong impact on the development of pulmonary hypertension in COPD. COPD patients with pulmonary hypertension had higher plasma levels than those without pulmonary hypertension and the levels of IL6 correlated with the mPAP [33]. A further association was found between the presence of pulmonary hypertension in COPD patients and polymorphisms of the IL- 6 gene: patients with the GG phenotype $(-174 \mathrm{G} / \mathrm{C})$ of the IL- 6 gene had higher pulmonary pressure than patients with the CC or GC phenotype [33,34]. These data indicate that variations in the genes encoding inflammatory cytokines might contribute to the development of pulmonary hypertension. About 6\% of patients with liver cirrhosis develop PAH (portopulmonary hypertension, PPHTN) [35]. In these patients, IL-6 was found to be significantly increased compared to cirrhosis patients without elevation of the pulmonary pressure [36].

Experimental evidence: Increased levels of IL-6 mRNA were measured in MCT rats that developed pulmonary hypertension and right ventricular hypertrophy (RVH). When these rats were treated with immunosuppressive steroids decreased levels of IL- 6 and reduced pulmonary pressures and RVH were measured [37]. Similar findings were obtained in mice by injections of supraphysiological doses of IL-6 that resulted in pulmonary hypertension, an effect that was even pronounced under hypoxic conditions [38]. The most convincing data for the role of IL-6 were reported by Steiner et al. that employed transgenic mice overexpressing IL-6. These animals showed enhanced muscularization both of the proximal arterial tree and in the distal arteriolar vessels and were found to have occlusive neointimal angioproliferative lesions, mostly consisting of endothelial cells and T-lymphocytes. These vasculopathic changes corresponded to the increase of right ventricular systolic pressure and RVH $[39,40]$.

As mentioned before, BMPR2 mutations might be found in about $70 \%$ of familial PAH and in up to $30 \%$ of idiopathic PAH patients. Of interest, however, dysregulation of the BMPR2 receptor has also been found in other forms of pulmonary hypertension. In an experimental model, Takahashi et al. found a significant downregulation of BMPR2 in rodents exposed to hypoxia [41]. Since these changes could not be correlated with adequate changes of the corresponding mRNA levels, a finding also confirmed by the MCT model of experimental pulmonary hypertension [42], Brock et al. identified a posttranscriptional mechanism to be responsible for the downregulation of BMPR2, involving IL-6, the signal transducer and activator of transcription STAT3 and the microRNA cluster $17 / 92$ [43].

Subsequent studies showed that specific inhibition of these microRNAs by antagomiRs were found to restore functional levels of BMPR2 and to inhibit or even reverse the vascular remodeling and subsequent hemodynamic alterations $[44,45]$. 
In addition, IL-6 might contribute to vascular remodeling also through other, miR-independent pathways. For example, it was shown that elevated levels of IL-6 resulted in an upregulation of vascular endothelial growth factor receptor II (VEGFR2) and matrix metalloproteinase-9 (MMP-9), an endopeptidase that promotes angiogenesis through regulation of cell attachment, proliferation, and migration. MMP-9 itself was found to upregulate VEGFR2, whereas levels of the ligand, VEGF, are increased by IL-6 directly. As such, high levels of IL-6 continuously activate the proliferation of PASMCs and probably trigger the transformation of pulmonary endothelial cells to pulmonary arterial smooth muscle cells [39].

Potential implications: IL-6 seems to be one of the most important inflammatory cytokines in the development of $\mathrm{PAH}$, and in particular of hypoxia-induced pulmonary hypertension. The IL6 - STAT3 - miR-17/92 - BMPR2 pathway is an attractive tool that contributed to the understanding of the pathogenesis of the pulmonary arterial remodeling and, in the future, might be further translated into the development of a causative treatment (Figure 2).

\section{IL-8}

Clinical data: Elevated serum levels of IL-8 were found in PAH patients and were also described as predictor of survival in PAH patients [21]. IL-8 is thought to play an important role in the development of $\mathrm{PAH}$, especially in early phases of vascular remodeling. IL-8 is known to have proangiogenic and antiapoptotic activities and acts as a growth factor for endothelial cells [46]. These effects could also explain why patients with PAH in association with connective tissue diseases show higher IL-8 serum

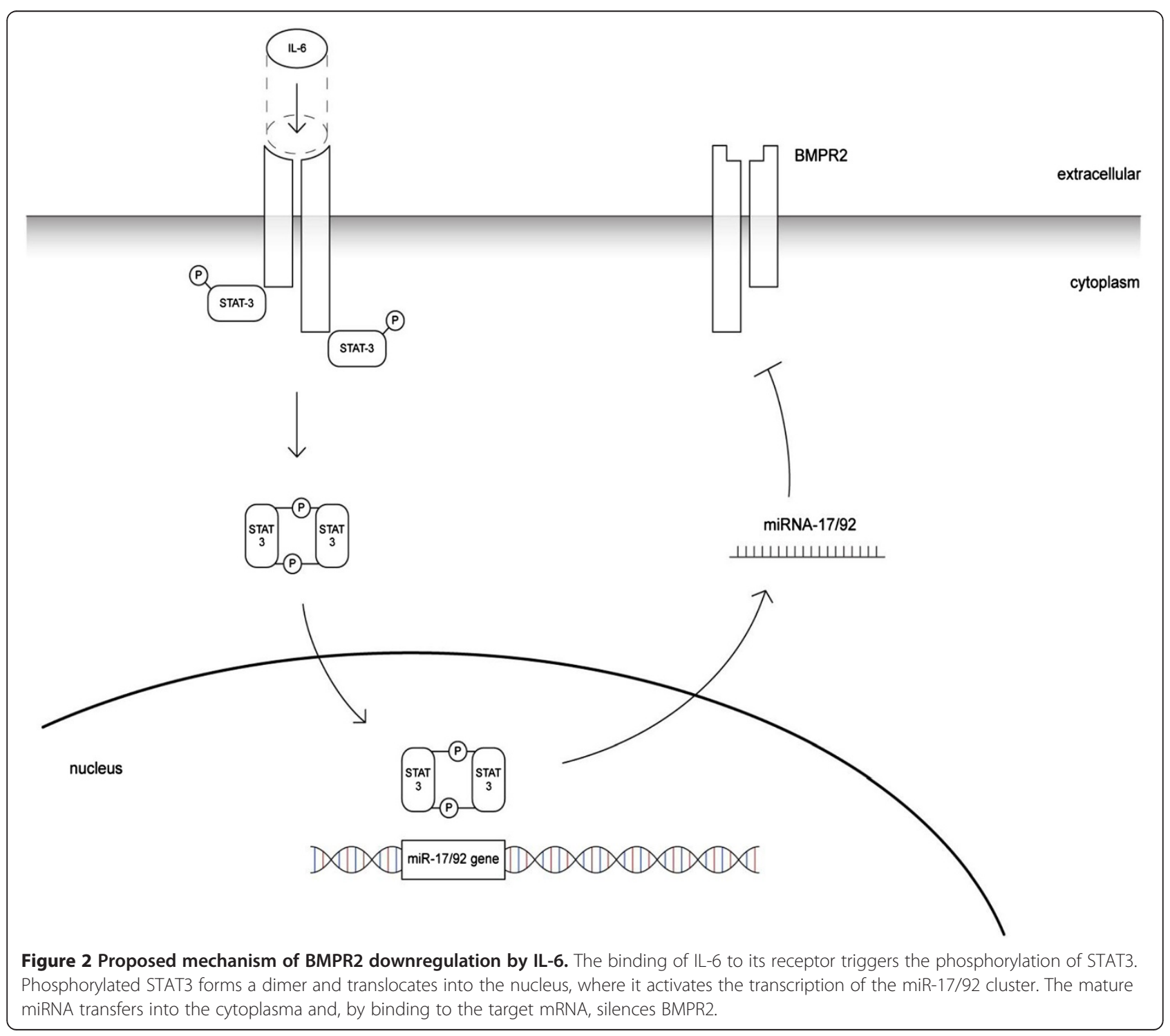


levels than patients without PAH [47]. Levels of IL-8 are elevated in early stages of high altitude pulmonary edema implicating that IL-8 might be involved in the hypoxic pressure response of pulmonary vessels [48].

Experimental evidence: Downregulation of the C-C chemokine receptor type 7 (CCR7), a regulator of lymphocyte trafficking [49], was described in patients with PAH. This deficiency leads to perivascular infiltration of $\mathrm{T}$ and $\mathrm{B}$ cells in mouse lungs, similarly to the findings observed in human PAH [50]. CCR7 -/-mice show elevated mRNA levels of IL-12 that - since IL-12 acts upstream of IL-8 in bronchial epithelial cells - [51] triggers the release of IL-8 [52].

\section{IL-10}

IL-10, released by T-cells, is one of the most important anti-inflammatory cytokines that inhibit overreaching inflammatory processes.

Clinical data: Elevated levels of IL-10 are found in patients with $\mathrm{PAH}$, which could serve as counterregulating mechanisms against the inflammation in lung tissue. The elevated IL-10 levels were found to be inversely correlated with prostacyclin agonists therapy, i.e. patients under a PHtarget therapy with prostacyclin agonists showed higher levels of IL-10 compared to patients without such therapy [21]. Conversely, PAH patients showed a significant decrease in IL-10 expression following cardiopulmonary bypass operation [53].

Experimental evidence: Ito et al. demonstrated that injections of IL-10 reduced the mean pulmonary arterial pressure in MCT rats and significantly improved survival [54].

Potential conclusion: Whether these observations reflect "true mechanisms" or represent an abnormal response remain unclear at the moment. In fact, since intravenous prostacyclin agonists are indicated for severe disease the correlation between levels of IL-10 and intravenous PH target therapy might be biased and it cannot be excluded that levels of IL-10 correlate with the severity of PAH $[21,22]$. Experimental data, however, suggest a protective role of the anti-inflammatory cytokine IL-10.

\section{IL-13}

Experimental evidence: According to previous research data, IL-13 acts as an important mediator of cell proliferation and tissue remodeling in lungs [55]. In experimental pulmonary hypertension the role of IL-13 remains ambiguous. IL-13 acts mainly through two receptors: the low affinity receptor IL-13R $\alpha 1$ and the high affinity receptor IL-13R $\alpha 2$. The IL-13R $\alpha 2$ is a 'decoy' receptor and acts as a strong and selective IL-13 signaling inhibitor. Both IL-13 and IL-13R $\alpha 2$ are found highly expressed in pulmonary vessels of PAH patients. Hecker et al. showed by in vitro experiments that addition of Il-13 decreased proliferation of PASMC, an effect that was pronounced by silencing IL-13R $\alpha 2$. Conversely, Graham et al. demonstrated that infection with the parasite Schistosoma mansoni resulted in PAH and remodeling of pulmonary arteries. Since this finding was pronounced in mice lacking IL$13 R \alpha 2$, the pro-proliferative effects on pulmonary vessels observed in Schistosomiasis are probably mediated by the eosinophilic effector cytokine IL-13 [56].

Further evidence for a role of IL-13 to promote vascular remodeling in pulmonary hypertension comes from Cho et al. that investigated an IL-13 - IL-13R $\alpha 2$ - Arginase 2 (Arg 2) pathway. Arg2 is a key enzyme of the L-arginine metabolism and was found to be induced by IL-13 in lung tissue from mice [57]. It is thought that Arg2 contributes to pulmonary hypertension mainly by competing with nitric oxide (NO)-synthase for the substrate arginine, leading to reduced bioavailability of the vasodilating NO [58]. Moreover, the enzymatic reaction of Arg2 itself appears to generate pro-proliferative factors [59]. Consistent with these findings, in Arg2 -/-mice overexpressing IL-13 remodeling of pulmonary arteries was found to be decreased [60].

Potential conclusion: IL-13 promotes the development of pulmonary hypertension via an IL-13 - IL-13R $\alpha 2$ Arg2 pathway leading to an imbalance of NO homeostasis and increased muscularization of pulmonary arteries. However, the experimental data show both protective and deleterious effects of IL-13 and it is too early to make conclusions on the potential use of IL-13 and its pathways as therapeutic target for pulmonary hypertension.

\section{TNF- $a$}

Clinical data: Similarly to other inflammatory cytokines, elevated serum levels of tumor necrosis factor (TNF)- $\alpha$ were described in PAH patients [21]. Moreover, COPD patients with pulmonary hypertension show significantly higher TNF- $\alpha$ and C-reactive protein levels than COPD patients without pulmonary hypertension, further corroborating the role of COPD as an inflammatory systemic disease [61].

Experimental evidence: When used in high concentrations, TNF- $\alpha$ suppresses the mRNA expression of the vasodilating PGI2 [26]. Injections of TNF- $\alpha$ to rats also increased vascular reactivity, which might contribute to pulmonary hypertension [62]. Similarly, TNF- $\alpha$ over expression in alveolar type II cells resulted in chronic pulmonary inflammation, septal destruction, bronchiolitis and pulmonary hypertension [63].

Sutendra et al. hypothesized that increased levels of TNF$\alpha$ may lead to a decrease of pyruvate dehydrogenase (PDH). $\mathrm{PDH}$ is a mitochondrial gate-keeping enzyme and may play an important role by making pulmonary arterial smooth muscle cells resistant to apoptosis. It could be demonstrated that the PDH activity was significantly decreased in cells treated with TNF- $\alpha$, while MCT-treated rats that 
were injected with Etanercept (a TNF- $\alpha$ antagonist) were found to be protected from development of PAH [64]. In another study, rats treated with a TNF- $\alpha$ blocker (rhTNFRFc) showed some amelioration in pulmonary hemodynamics, right ventricular hypertrophy and pulmonary inflammation [65] and in pigs with endotoxemicshock-induced pulmonary hypertension, Etanercept was able to lower both pulmonary arterial pressure and pulmonary vascular resistance compared to pigs without Etanercept therapy [66]. Other studies using TNF- $\alpha$ antagonists, however, could not confirm an improvement of pulmonary hypertension $[67,68]$.

Potential conclusion: TNF- $\alpha$ might play an important role in the development of pulmonary hypertension, even though the concrete mechanisms remain unknown. Interestingly some studies show that TNF- $\alpha$ blockers ameliorate pulmonary pressure, while other studies found no significant effects.

\section{Conclusions}

Inflammatory cytokines seem to play a crucial role in the development of pulmonary hypertension. However, while experimental research has contributed a lot to our understanding of the pathogenesis and development of this devastating disease, it remains difficult to provide an integrative pathway for the different identified factors and to translate these findings to human pulmonary hypertension, which remains a challenge for future research in the field. Since the cytokines discussed in this article and the cells that release them and respond to them probably form a complex network with different signaling pathways involved, many conclusions on the role of inflammatory cytokines for pathogenesis and treatment of pulmonary hypertension remain speculative so far. Moreover, due to the multiple and redundant activation of pathways and the interaction of many cytokines, targeting one specific factor might not prove successful in a clinical setting.

It is the authors' view that the best-investigated and most promising cytokine to date is IL-6, in particular for the development of hypoxia-induced pulmonary hypertension. Research focusing on the pathway of IL-6, involving the action of microRNAs and regulation of the expression of BMPR2 thus is ongoing to extend these findings to other forms of pulmonary hypertension or the use of these factors as surrogate markers for the disease.

\footnotetext{
Abbreviations

Arg2: Arginase 2; ATP: Adenosintriphosphate; BMPR2: Bone morphogenetic protein receptor type 2; CAMP: Cyclic adenosine monophosphate; CCR7: C-C chemokine receptor type 7; COPD: Chronic obstructive pulmonary disease; COX: Cyclooxygenase; CTEPH: Chronic thromboembolic pulmonary hypertension; ET-1: Endothlin-1; IL: Interleukin; IL-13Ra1: Interleukin-13 receptor a1; IL-13Ra2: Interleukin-13 receptor a2; IL-18Ra: Interleukin-18 receptor a; 6-keto-PGF1a: 6-keto Prostaglandin F1a; MCl: 1-[o-(m-methoxyphenyl) ethyl]phenoxy]-3-(dimethylamino)-2-propyl hydrogen succinate hydrochloride; MCT: Monocrotaline; MMP-9: Matrix metallopeptidase 9; mPAP: Mean pulmonary arterial pressure; miR: Micro RNA; mRNA: Messenger RNA; NFAT: Nuclear
}

factor of activated T-cells; NO: Nitric oxide; NYHA: New York Heart Association; PAH: Pulmonary arterial hypertension; PASMC: Pulmonary artery smooth muscle cells; PDH: Pyruvate dehydrogenase; PGI2: Prostaglandin 12; PPHTN: Portopulmonary hypertension; rhTNFRFc: Recombinant tumor necrosis factor receptor:Fc fusion protein; RVH: Right ventricular hypertrophy; STAT3: Signal transducer and activator of transcription 3; TNF-a: Tumor necrosis factor-alpha; TGF 32 : Transforming growth factor-beta 2; VEGF: Vascular endothelial growth factor; VEGFR2: Vascular endothelial growth factor receptor 2.

\section{Competing interests}

The project "the role of microRNAs in pulmonary hypertension: diagnosis and treatment" is supported by the Swiss National Science Foundation (SNF 31003A_144212) and the Zurich Lung Foundation. The authors declare that they have no competing interests.

\section{Authors' contributions}

AG performed literature search and wrote drafts and revisions of the manuscript. BV provided Figure 2 and assisted to write the final version of the mansucript. MB reviewed all versions of the manuscript and assisted to write the final version. RS reviewed all versions of the manuscript and assisted to write the final version. SU reviewed all versions of the manuscript and assisted to write the final version. LH supervision of AG. assisted to write all drafts and revisions and wrote the final version. All authors read and approved the final manuscript.

\section{Author details}

'Division of Pulmonology, University Hospital Zurich, Rämistrasse 100, CH-8091 Zurich, Switzerland. ${ }^{2}$ Institute of Surgical Pathology, University Hospital Zurich, Rämistrasse 100, CH-8091 Zurich, Switzerland.

Received: 25 October 2013 Accepted: 8 April 2014

Published: 16 April 2014

\section{References}

1. Simonneau G, Gatzoulis MA, Adatia I, Celermajer D, Denton C, Ghofrani A, Gomez Sanchez MA, Krishna Kumar R, Landzberg M, Machado RF, Olschewski H, Robbins IM, Souza R: Updated clinical classification of pulmonary hypertension. J Am Coll Cardiol 2013, 62:D34-D41.

2. Farber HW, Loscalzo J: Pulmonary arterial hypertension. N Engl J Med 2004 351:1655-1665.

3. Cool CD, Kennedy D, Voelkel NF, Tuder RM: Pathogenesis and evolution of plexiform lesions in pulmonary hypertension associated with scleroderma and human immunodeficiency virus infection. Hum Pathol 1997, 28:434-442.

4. Stacher E, Graham BB, Hunt JM, Gandjeva A, Groshong SD, McLaughlin W, Jessup M, Grizzle WE, Aldred MA, Cool CD, Tuder RM: Modern age pathology of pulmonary arterial hypertension. Am J Respir Crit Care Med 2012, 186:261-272.

5. Thurnheer R, Jenni R, Russi EW, Greminger P, Speich R: Hyperthyroidism and pulmonary hypertension. J Intern Med 1997, 242:185-188.

6. Fagan KA, Badesch DB: Pulmonary hypertension associated with connective tissue disease. Prog Cardiovasc Dis 2002, 45:225-234.

7. Gerasimovskaya E, Kratzer A, Sidiakova A, Salys J, Zamora M, Taraseviciene-Stewart L: Interplay of macrophages and T cells in the lung vasculature. Am J Physiol Lung Cell Mol Physiol 2012, 302:L1014-L1022.

8. Stow JL, Low PC, Offenhäuser C, Sangermani D: Cytokine secretion in macrophages and other cells: pathways and mediators. Immunobiology 2009, 214:601-612.

9. Wilson HM, Barker RN, Erwig LP: Macrophages: promising targets for the treatment of atherosclerosis. Curr Vasc Pharmacol 2009, 7:234-243.

10. Vergadi E, Chang MS, Lee C, Liang OD, Liu X, Fernandez-Gonzalez A, Mitsialis SA, Kourembanas S: Early macrophage recruitment and alternative activation are critical for the later development of hypoxia-induced pulmonary hypertension. Circulation 2011, 123:1986-1995.

11. Roca H, Varsos ZS, Sud S, Craig MJ, Ying C, Pienta KJ: CCL2 and interleukin-6 promote survival of human CD11b + peripheral blood mononuclear cells and induce M2-type macrophage polarization. J Biol Chem 2009, 284:34342-34354.

12. Savai R, Pullamsetti SS, Kolbe J, Bieniek E, Voswinckel R, Fink L, Scheed A, Ritter C, Dahal BK, Vater A, Klussmann S, Ghofrani HA, Weissmann N, 
Klepetko W, Banat GA, Seeger W, Grimminger F, Schermuly RT: Immune and inflammatory cell involvement in the pathology of idiopathic pulmonary arterial hypertension. Am J Respir Crit Care Med 2012, 186:897-908.

13. Edwards AL, Gunningham SP, Clare GC, Hayman MW, Smith M, Frampton CM, Robinson BA, Troughton RW, Beckert LE: Professional killer cell deficiencies and decreased survival in pulmonary arterial hypertension (PAH). Respirology 2013, 18:1271-1277.

14. Tamosiuniene R, Nicolls MR: Regulatory $T$ cells and pulmonary hypertension. Trends Cardiovasc Med 2011, 21:166-171.

15. Rich S, Kieras K, Hart K, Groves BM, Stobo JD, Brundage BH: Antinuclear antibodies in primary pulmonary hypertension. J Am Coll Cardiol 1986, 8:1307-1311.

16. Ulrich S, Taraseviciene-Stewart L, Huber LC, Speich R, Voelkel N: Peripheral blood $\mathrm{B}$ lymphocytes derived from patients with idiopathic pulmonary arterial hypertension express a different RNA pattern compared with healthy controls: a cross sectional study. Respir Res 2008, 9:20.

17. Price LC, Wort SJ, Perros F, Dorfmüller P, Huertas A, Montani D, Cohen-Kaminsky S, Humbert M: Inflammation in pulmonary arterial hypertension. Chest 2012, 141:210-221.

18. Dorfmüller P, Zarka V, Durand-Gasselin I, Monti G, Balabanian K, Garcia G, Capron F, Coulomb-Lherminé A, Marfaing-Koka A, Simonneau G, Emilie D, Humbert M: Chemokine RANTES in severe pulmonary arterial hypertension. Am J Respir Crit Care Med 2002, 165:534-539.

19. Balabanian K, Foussat A, Dorfmüller P, Durand-Gasselin I, Capel F, Bouchet-Delbos L, Portier A, Marfaing-Koka A, Krzysiek R, Rimaniol AC, Simonneau G, Emilie D, Humbert M: CX(3)C chemokine fractalkine in pulmonary arterial hypertension. Am J Respir Crit Care Med 2002, 165:1419-1425.

20. West J, Hemnes A: Experimental and transgenic models of pulmonary hypertension. Compr Physio/ 2011, 1:769-782.

21. Soon E, Holmes AM, Treacy CM, Doughty NJ, Southgate L, Machado RD, Trembath RC, Jennings S, Barker L, Nicklin P, Walker C, Budd DC, Pepke-Zaba J, Morrell NW: Elevated levels of inflammatory cytokines predict survival in idiopathic and familial pulmonary arterial hypertension. Circulation 2010, 122:920-927.

22. Campos M, Schiopu E: Pulmonary arterial hypertension in adult-onset still's disease: rapid response to Anakinra. Case Rep Rheumatol 2012, 2012:537613.

23. Voelkel NF, Tuder RM, Bridges J, Arend WP: Interleukin-1 receptor antagonist treatment reduces pulmonary hypertension generated in rats by monocrotaline. Am J Respir Cell Mol Biol 1994, 11:664-675.

24. Tuder RM, Cool CD, Geraci MW, Wang J, Abman SH, Wright L, Badesch D, Voelkel NF: Prostacyclin synthase expression is decreased in lungs from patients with severe pulmonary hypertension. Am J Respir Crit Care Med 1999, 159:1925-1932.

25. Wen FQ, Watanabe K, Tanaka H, Yoshida M: Cytokines and lipopolysaccharide enhance basal and thrombin-stimulated production of PGI2 by cultured human pulmonary artery smooth muscle cells. Prostaglandins Leukot Essent Fatty Acids 1997, 56:185-192.

26. Itoh A, Nishihira J, Makita H, Miyamoto K, Yamaguchi E, Nishimura M: Effects of IL-1 beta, TNF-alpha, and macrophage migration inhibitory factor on prostacyclin synthesis in rat pulmonary artery smooth muscle cells. Respirology 2003, 8:467-472.

27. Bradbury DA, Newton R, Zhu YM, Stocks J, Corbett L, Holland ED, Pang LH, Knox AJ: Effect of bradykinin, TGF-beta1, IL-1beta, and hypoxia on COX-2 expression in pulmonary artery smooth muscle cells. Am J Physiol Lung Cell Mol Physiol 2002, 283:L717-L725.

28. El-Haroun H, Bradbury D, Clayton A, Knox AJ: Interleukin-1beta, transforming growth factor-beta1, and bradykinin attenuate cyclic AMP production by human pulmonary artery smooth muscle cells in response to prostacyclin analogues and prostaglandin E2 by cyclooxygenase-2 induction and downregulation of adenylyl cyclase isoforms 1,2 , and 4 . Circ Res 2004, 94:353-361.

29. Ross DJ, Strieter RM, Fishbein MC, Ardehali A, Belperio JA: Type I immune response cytokine-chemokine cascade is associated with pulmonary arterial hypertension. J Heart Lung Transplant 2012, 31:865-873.

30. Brock M, Trenkmann M, Gay RE, Gay S, Speich R, Huber LC: MicroRNA-18a enhances the interleukin-6-mediated production of the acute-phase proteins fibrinogen and haptoglobin in human hepatocytes. J Biol Chem 2011, 286:40142-40150.
31. Humbert M, Monti G, Brenot F, Sitbon O, Portier A, Grangeot-Keros L, Duroux P, Galanaud P, Simonneau G, Emilie D: Increased interleukin-1 and interleukin-6 serum concentrations in severe primary pulmonary hypertension. Am J Respir Crit Care Med 1995, 151:1628-1631.

32. Selimovic $N$, Bergh $\mathrm{CH}$, Andersson B, Sakiniene $\mathrm{E}$, Carlsten $H$, Rundqvist B: Growth factors and interleukin- 6 across the lung circulation in pulmonary hypertension. Eur Respir J 2009, 34:662-668.

33. Chaouat A, Savale L, Chouaid C, Tu L, Sztrymf B, Canuet M, Maitre B, Housset B, Brandt C, Le Corvoisier P, Weitzenblum E, Eddahibi S, Adnot S: Role for interleukin-6 in COPD-related pulmonary hypertension. Chest 2009, 136:678-687.

34. Eddahibi S, Chaouat A, Tu L, Chouaid C, Weitzenblum E, Housset B, Maitre B, Adnot S: Interleukin-6 gene polymorphism confers susceptibility to pulmonary hypertension in chronic obstructive pulmonary disease. Proc Am Thorac Soc 2006, 3:475-476.

35. Kawut SM, Krowka MJ, Trotter JF, Roberts KE, Benza RL, Badesch DB, Taichman DB, Horn EM, Zacks S, Kaplowitz N, Brown RS Jr, Fallon MB: Clinical risk factors for portopulmonary hypertension. Hepatology 2008, 48:196-203.

36. Pellicelli AM, Barbaro G, Puoti C, Guarascio P, Lusi EA, Bellis L, D'Ambrosio C, Villani R, Vennarecci G, Liotta G, Ettore G, Andreoli A: Plasma cytokines and portopulmonary hypertension in patients with cirrhosis waiting for orthotopic liver transplantation. Angiology 2010, 61:802-806.

37. Bhargava A, Kumar A, Yuan N, Gewitz MH, Mathew R: Monocrotaline induces interleukin-6 mRNA expression in rat lungs. Heart Dis 1999, 1:126-132.

38. Golembeski SM, West J, Tada Y, Fagan KA: Interleukin- 6 causes mild pulmonary hypertension and augments hypoxia-induced pulmonary hypertension in mice. Chest 2005, 128:572S-573S.

39. Steiner MK, Syrkina OL, Kolliputi N, Mark EJ, Hales CA, Waxman AB: Interleukin-6 overexpression induces pulmonary hypertension. Circ Res 2009, 104:236-244. 228p following 244.

40. Savale L, Tu L, Rideau D, Izziki M, Maitre B, Adnot S, Eddahibi S: Impact of interleukin-6 on hypoxia-induced pulmonary hypertension and lung inflammation in mice. Respir Res 2009, 10:6.

41. Takahashi H, Goto N, Kojima Y, Tsuda Y, Morio Y, Muramatsu M, Fukuchi Y: Downregulation of type II bone morphogenetic protein receptor in hypoxic pulmonary hypertension. Am J Physiol Lung Cell Mol Physiol 2006, 290:L450-L458.

42. Morty RE, Nejman B, Kwapiszewska G, Hecker M, Zakrzewicz A, Kouri FM, Peters DM, Dumitrascu R, Seeger W, Knaus P, Schermuly RT, Eickelberg O: Dysregulated bone morphogenetic protein signaling in monocrotalineinduced pulmonary arterial hypertension. Arterioscler Thromb Vasc Biol 2007, 27:1072-1078.

43. Brock M, Trenkmann M, Gay RE, Michel BA, Gay S, Fischler M, Ulrich S, Speich R, Huber LC: Interleukin-6 modulates the expression of the bone morphogenic protein receptor type II through a novel STAT3-microRNA cluster 17/92 pathway. Circ Res 2009, 104:1184-1191.

44. Pullamsetti SS, Doebele C, Fischer A, Savai R, Kojonazarov B, Dahal BK, Ghofrani HA, Weissmann N, Grimminger F, Bonauer A, Seeger W, Zeiher AM, Dimmeler S, Schermuly RT: Inhibition of microRNA-17 improves lung and heart function in experimental pulmonary hypertension. Am J Respir Crit Care Med 2012, 185:409-419.

45. Brock M, Samillan VJ, Trenkmann M, Schwarzwald C, Ulrich S, Gay RE Gassmann M, Ostergaard L, Gay S, Speich R, Huber LC: AntagomiR directed against miR-20a restores functional BMPR2 signalling and prevents vascular remodelling in hypoxia-induced pulmonary hypertension. Eur Heart J 2012. e-publication only.

46. Li A, Varney ML, Valasek J, Godfrey M, Dave BJ, Singh RK: Autocrine role of interleukin-8 in induction of endothelial cell proliferation, survival, migration and MMP-2 production and angiogenesis. Angiogenesis 2005, 8:63-71.

47. Riccieri V, Stefanantoni K, Vasile M, Macrì V, Sciarra I, lannace N, Alessandri C, Valesini G: Abnormal plasma levels of different angiogenic molecules are associated with different clinical manifestations in patients with systemic sclerosis. Clin Exp Rheumatol 2011, 29:S46-S52.

48. Kubo K, Hanaoka M, Hayano T, Miyahara T, Hachiya T, Hayasaka M, Koizumi T, Fujimoto K, Kobayashi T, Honda T: Inflammatory cytokines in BAL fluid and pulmonary hemodynamics in high-altitude pulmonary edema. Respir Physiol 1998, 111:301-310

49. Bull TM, Coldren CD, Moore M, Sotto-Santiago SM, Pham DV, Nana-Sinkam SP, Voelkel NF, Geraci MW: Gene microarray analysis of peripheral blood cells in 
pulmonary arterial hypertension. Am J Respir Crit Care Med 2004, 170:911-919.

50. Höpken UE, Wengner AM, Loddenkemper C, Stein H, Heimesaat MM, Rehm A, Lipp M: CCR7 deficiency causes ectopic lymphoid neogenesis and disturbed mucosal tissue integrity. Blood 2007, 109:886-895.

51. Ogawa H, Nishimura N, Nishioka Y, Azuma M, Yanagawa H, Sone S: Adenoviral interleukin-12 gene transduction into human bronchial epithelial cells: up-regulation of pro-inflammatory cytokines and its prevention by corticosteroids. Clin Exp Allergy 2003, 33:921-929.

52. Larsen KO, Yndestad A, Sjaastad I, Løberg EM, Goverud IL, Halvorsen B, Jia J, Andreassen AK, Husberg C, Jonasson S, Lipp M, Christensen G, Aukrust P, Skjønsberg OH: Lack of CCR7 induces pulmonary hypertension involving perivascular leukocyte infiltration and inflammation. Am J Physiol Lung Cell Mol Physiol 2011, 301:L50-L59.

53. Lei $Y$, Zhen J, Ming XL, Jian HK: Induction of higher expression of IL-beta and TNF-alpha, lower expression of IL-10 and cyclic guanosine monophosphate by pulmonary arterial hypertension following cardiopulmonary bypass. Asian J Surg 2002, 25:203-208.

54. Ito T, Okada T, Miyashita H, Nomoto T, Nonaka-Sarukawa M, Uchibori R, Maeda Y, Urabe M, Mizukami H, Kume A, Takahashi M, Ikeda U, Shimada K, Ozawa K: Interleukin-10 expression mediated by an adeno-associated virus vector prevents monocrotaline-induced pulmonary arterial hypertension in rats. Circ Res 2007, 101:734-741.

55. Wynn TA: Fibrotic disease and the $T(H) 1 / T(H) 2$ paradigm. Nat Rev Immunol 2004, 4:583-594.

56. Graham BB, Mentink-Kane MM, El-Haddad H, Purnell S, Zhang L, Zaiman A, Redente EF, Riches DW, Hassoun PM, Bandeira A, Champion HC, Butrous G, Wynn TA, Tuder RM: Schistosomiasis-induced experimental pulmonary hypertension: role of interleukin-13 signaling. Am J Pathol 2010, 177:1549-1561.

57. Zimmermann N, King NE, Laporte J, Yang M, Mishra A, Pope SM, Muntel EE, Witte DP, Pegg AA, Foster PS, Hamid Q, Rothenberg ME: Dissection of experimental asthma with DNA microarray analysis identifies arginase in asthma pathogenesis. J Clin Invest 2003, 111:1863-1874.

58. Xu W, Kaneko FT, Zheng S, Comhair SA, Janocha AJ, Goggans T, Thunnissen FB, Farver C, Hazen SL, Jennings C, Dweik RA, Arroliga AC, Erzurum SC: Increased arginase II and decreased NO synthesis in endothelial cells of patients with pulmonary arterial hypertension. FASEB J 2004, 18:1746-1748.

59. Morris SM: Recent advances in arginine metabolism: roles and regulation of the arginases. Br J Pharmacol 2009, 157:922-930.

60. Cho WK, Lee CM, Kang MJ, Huang Y, Giordano FJ, Lee PJ, Trow TK, Homer RJ, Sessa WC, Elias JA, Lee CG: IL-13 receptor a2-arginase 2 pathway mediates IL-13-induced pulmonary hypertension. Am J Physiol Lung Cell Mol Physiol 2013, 304:L112-L124

61. Joppa P, Petrasova D, Stancak B, Tkacova R: Systemic inflammation in patients with COPD and pulmonary hypertension. Chest 2006, 130:326-333.

62. Stevens T, Janssen PL, Tucker A: Acute and long-term TNF-alpha administration increases pulmonary vascular reactivity in isolated rat lungs. J Appl Physiol 1992, 73:708-712.

63. Fujita M, Shannon JM, Irvin CG, Fagan KA, Cool C, Augustin A, Mason RJ: Overexpression of tumor necrosis factor-alpha produces an increase in lung volumes and pulmonary hypertension. Am J Physiol Lung Cell Mol Physiol 2001, 280:L39-L49.

64. Sutendra G, Dromparis P, Bonnet S, Haromy A, McMurtry MS, Bleackley RC, Michelakis ED: Pyruvate dehydrogenase inhibition by the inflammatory cytokine TNFa contributes to the pathogenesis of pulmonary arterial hypertension. J Mol Med (Berl) 2011, 89:771-783.

65. Wang Q, Zuo XR, Wang YY, Xie WP, Wang H, Zhang M: Monocrotaline-induced pulmonary arterial hypertension is attenuated by TNF-a antagonists via the suppression of TNF-a expression and NF-KB pathway in rats. Vascul Pharmacol 2013, 58:71-77.

66. Mutschler D, Wikström G, Lind L, Larsson A, Lagrange A, Eriksson M: Etanercept reduces late endotoxin-induced pulmonary hypertension in the pig. J Interferon Cytokine Res 2006, 26:661-667.
67. Henriques-Coelho T, Brandão-Nogueira A, Moreira-Gonçalves D, Correia-Pinto J, Leite-Moreira AF: Effects of TNF-alpha blockade in monocrotaline-induced pulmonary hypertension. Rev Port Cardiol 2008, 27:341-348.

68. Chung ES, Packer M, Lo KH, Fasanmade AA, Willerson JT, Investigators A-TTACHF: Randomized, double-blind, placebo-controlled, pilot trial of infliximab, a chimeric monoclonal antibody to tumor necrosis factoralpha, in patients with moderate-to-severe heart failure: results of the anti-TNF Therapy Against Congestive Heart Failure (ATACH) trial. Circulation 2003, 107:3133-3140.

doi:10.1186/1465-9921-15-47

Cite this article as: Groth et al:: Inflammatory cytokines in pulmonary hypertension. Respiratory Research 2014 15:47.

\section{Submit your next manuscript to BioMed Central and take full advantage of:}

- Convenient online submission

- Thorough peer review

- No space constraints or color figure charges

- Immediate publication on acceptance

- Inclusion in PubMed, CAS, Scopus and Google Scholar

- Research which is freely available for redistribution

Submit your manuscript at www.biomedcentral.com/submit
() Biomed Central 